\title{
Lime and phosphate effects on atrazine sorption, leaching and runoff in soil
}

\author{
Efeito de calcário e fosfato na sorção, lixiviação e transporte de \\ atrazina por erosão em solo
}

\author{
José Maria de Lima ${ }^{*}\left(\mathbb{D}\right.$, Regimeire Freitas Aquino² ${ }^{\mathbb{D}}$, Ciro Augusto de Souza Magalhães ${ }^{3}(\mathbb{D}$, \\ Raissa Homem Gonçalves ${ }^{1}$ (D) Júlio Cesar Azevedo Nóbrega ${ }^{1}$ (D) Carlos Rogério Mello ${ }^{4}$ (D)
}

\author{
'Universidade Federal do Recôncavo da Bahia/UFRB, Centro de Ciências Agrárias, Ambientais e Biológicas, Cruz das Almas, BA, Brasil \\ ${ }^{2}$ Centro Federal de Educação Tecnológica de Minas Gerais/CEFET-MG, Departamento de Engenharia Civil, Belo Horizonte, MG, Brasil \\ ${ }^{3}$ Empresa Brasileira de Pesquisa Agropecuária/Embrapa, Embrapa Agrossilvipastoril, Sinop, MT, Brasil \\ ${ }^{4}$ Universidade Federal de Lavras/UFLA, Departamento de Recursos Hídricos e Saneamento, Lavras, MG, Brasil \\ *Corresponding author:jml.dcs@gmail.com \\ Received in September 27, 2019 and approved in March 11, 2020
}

\begin{abstract}
Atrazine still is a widely used herbicide in tropical soils to control annual broad-leaved weeds and annual grasses mainly in maize and sorghum plantations. Sorption and desorption in such soils are important processes that affect transport, ending with soil and water contamination, not only in these soils, but in other soils around the world. Lime and phosphate are important amendments in tropical soils to mitigate low fertility. These treatments can affect interaction among soil particles and between soil and atrazine. The objectives here were to evaluate the effect of lime, phosphate, and lime + phosphate treatments on sorption and transport of atrazine in a Typic Hapludult, using soil-erosion-plots at field conditions in a 3\%-slope landscape $20 \mathrm{~m}$ away from the floodplain. Water- and sediment-sampler devices were used to measure runoff during an entire rainy season. Soil, water and sediments were sampled and analyzed for atrazine. By increasing $\mathrm{pH}$ and changing soil organic matter interaction with mineral particles, lime and lime + phosphate decreased sorption in the upper 20-cm layer. This affected leaching and runoff of atrazine, showing that when lime and lime + phosphate were applied to soil, this herbicide had more potential to go deeper in the soil profile, towards the groundwater, or to runoff towards the lower part of the landscape. However, even with increasing leaching, the amount of rainfall, and water infiltration, were enough to dilute atrazine into levels below the maximum contaminant level $(\mathrm{MCL})$ of atrazine in drinking water.
\end{abstract}

Index terms: Contamination; pesticide; argisol; soil erosion plots.

\section{RESUMO}

A atrazina é um herbicida ainda amplamente utilizado em solos tropicais para controlar plantas daninhas de folhas largas anuais e gramíneas anuais principalmente nas culturas de milho e sorgo. A sorção e dessorção nesses solos são processos importantes que afetam o transporte, terminando com a contaminação do lençol freático e de mananciais de água superficial. A calagem e a fosfatagem são importantes práticas em solos tropicais para mitigar problemas de fertilidade. Esses tratamentos podem afetar a interação das partículas do solo com a atrazina. Neste trabalho foi avaliado o efeito de tratamentos calagem, da fosfatagem e da calagem + fosfatagem na sorção e transporte de atrazina em um Argissolo Vermelho Amarelo distrófico, em condições de campo, em parcelas de perdas de solo por erosão, numa paisagem de $3 \%$ de declive montadas a distância de $20 \mathrm{~m}$ da várzea. Dispositivos de amostragem de água e sedimentos foram usados para medir a erosão durante uma estação chuvosa de 2007 2008, comum para a região (outubro a abril). Solo, água e sedimentos foram amostrados para determinação de resíduos de atrazina. Os tratamentos com calagem e com calagem mais fosfatagem diminuíram a sorção da atrazina na camada superficial, por elevar o pH e afetar a interação entre a matéria orgânica do solo e suas partículas minerais, aumentando a lixiviação para as camadas inferiores do perfil do solo. Esse comportamento mostrou que a calagem e, principalmente, a calagem mais fosfatagem, facilitam a lixiviação do herbicida, evidenciando o potencial para contaminar a água do lençol freático. No entanto, a quantidade de chuva foi suficiente para aumentar a quantidade de água no lençol freático e diluir a quantidade de atrazina para níveis abaixo do limite aceitável para água potável.

Termos para indexação: Contaminação; pesticida; argissolo; parcelas de perda de solo. 


\section{INTRODUCTION}

Atrazine is an herbicide which is widely used in maize (Zea mays) crops (Aquino et al., 2013; Pignati et al., 2017), and has been employed for more than three decades to control annual grasses and broad-leaved weeds. Sorption and transport of atrazine have been widely studied in laboratory experiments and in fields were this product has been used for long time. However, fewer studies are conducted using soil-erosion plots, such as this one. Sorption, leaching and runoff influence the efficiency of this herbicide and its impact on the environment. Soil tillage may affect infiltration as well as surface runoff and soil moisture and interfere on the potential for sorption and transport, ending with groundwater pollution, especially in soils with a long history of atrazine application (Barrios et al., 2019). Soils play the role of natural filters during the process of sorbing organic contaminants applied to control pests, diseases, and weeds, such as insecticides, nematicides, fungicides, and herbicides. All these contaminants may impact soils and water, and indeed affect human health (Arora; Sahni, 2016). A long time of atrazine application causes its accumulation, which may persist for decades, representing a long-term threat to the environment (Vonberg et al., 2014). Although its use has been banned in many countries, such as in European Union (Sass; Colangelo, 2006), it is still broadly used in Brazil (Pignati et al., 2017).

The quantity and persistence of atrazine in soils depend on several factors. Its molecules are sorbed primarily by organic matter (humic substances, HS) and then by some mineral particles (Laird et al., 1994; Martins et al., 2018). The type of soil, its organic matter and clay content, and its $\mathrm{pH}$, which affects the charge and structure of humic acids (Herwig et al., 2001), as well as soil structure and fertility, may affect the sorption and transport of atrazine. The atrazine sorption behavior is dominated by the solid-state soil components, with the presence of dissolved organic matter (DOM) having a minor effect (Spark; Swift, 2002). It is a potential contaminant of water resources both by leaching and runoff (Aquino et al., 2013) due to its relatively high persistence in soils, slow hydrolysis, low to moderate solubility in water, and moderate adsorption to organic matter and clay particles (Mudhoo; Garg, 2011). The EPA's oversight of atrazine is dynamic and includes periodic re-evaluation and intensive monitoring programs in USA (USA Environmental Protection Agency - EPA, 2016).

In Brazil, studies on the presence and its removal from the water were analyzed, and atrazine detection frequencies were about $8 \%$ for surface water and $12 \%$ for groundwater as observed in the reviewed studies by Dias et al. (2018). Sorption, leaching or transporting of atrazine by sediments and water depends on the crop management systems, because it is frequently used fertilizers or lime to mitigate soil fertility limitations.

Lime and phosphate amendments are standard crop practices for tropical soils with low fertility and high iron and aluminum oxide contents. Therefore, the changes caused by these practices affect soil $\mathrm{pH}$ and charge balance with significant effect on the interaction with such compounds (Clay et al., 1988). Such amendments that affect $\mathrm{pH}$ and $\mathrm{OM}$ also impact sorption, desorption and leaching of atrazine in soils. Aggregation of humic acids in the presence of calcium ions implies that aggregates may temporarily trap and transport pollutants in the environment (Kloster, et al., 2013). Studies regarding the fate of atrazine in soils directly in the field are particularly relevant in soils that are chemically amended with lime and phosphate which change mainly soil $\mathrm{pH}$. The molecule's behavior as a weak base makes sorption on soil particles a component of retention or transport in soils. According to Yue et al. (2017), the atrazine sorption in their tested soils was dominated by physical sorption, at low equilibrium concentration, and by hydrophobic partitioning, as concentration equilibrium increases; they also found that desorption of atrazine is favored at lower solution $\mathrm{pH}$. Therefore, changing the soil chemical characteristics by lime and phosphate, such as increasing $\mathrm{pH}$, affecting organic compounds and increasing negative charge on particles, can potentially increase contamination of soil and water. However, level of contamination depends on soil amendments and having enough rain (Ouyang et al., 2016) that infiltrate the soil and dilute quantity of atrazine to levels below the tolerable limit to drink water, which is from where human health can be harmed.

Even though atrazine is widely studied, there is still little information in Brazil regarding its sorption and transport in soils evaluated under field conditions, especially considering leaching and erosion in soils undergoing changes due to lime and phosphate that are frequently applied to increase fertility in tropical conditions. Therefore, more accurate information on the potential leaching of herbicides, including atrazine, to groundwater in tropical soils is necessary (Oliveira Junior; Koskinen; Ferreira, 2001). This study monitored and evaluated the presence of atrazine in soil sediments and water from erosion plots on a dystrophic Typic Hapludult, and the effect of lime and phosphate on sorption, leaching and runoff in this soil, aiming to a better understanding and measurement of 
the behavior of atrazine this soil under field condition, as well as to assess the risk of contaminating the soil profile, groundwater, and nearby the wetlands.

\section{MATERIAL AND METHODS}

\section{Setup of soil erosion plots}

The plots were located in an Environmental Protection Area in the South of Minas Gerais State Brazil (210 $08^{\prime} 18.2^{\prime \prime} \mathrm{S}, 45^{\circ} 22^{\prime}$ 23" W), which had been used for pasture for ten years, where this herbicide had never been applied. According to Köppen and Geiger, this climate is classified as Cwa (Kottek et al. 2006). The average annual temperature is $20.4{ }^{\circ} \mathrm{C}$ and precipitation averages $1389 \mathrm{~mm}$. Experimental plots were set up at the lower third of a $3 \%$-slope landscape $20 \mathrm{~m}$ away from the floodplain. Before before setting up the soil erosion plots, the whole area was plowed and graded to $20-\mathrm{cm}$ depth. Then, each plot was separated using galvanized sheets and had an individual 9-splitter Geib device connected to a set of two 500-L containers in order to sample the surface runoff. Each plot was $2 \mathrm{~m}$ wide and $10 \mathrm{~m}$ long (Figure 1). The soil was an Argissolo Vermelho-Amarelo (Santos et al., 2018), a Typic Hapludult (Soil Survey Staff, 2014), and its physical and chemical characterization was performed according to Embrapa (2017). The physical characterization of soil was performed using the pipette method for particle size distribution. The chemical characterization, $\mathrm{pH}$ in water, cations from the sorptive complex, available phosphorus, and total organic carbon were determined in the soil samples before and after the preparation of the soil plots (Table 1). A weather station was assembled within the area so that weather events could be monitored.

The amount of rainfall and the level of the water table, which ranged from about 0.35 - to $1.20-\mathrm{m}$ depth during the experiment, are shown in Figure 2. Four soil conditions (i.e., treatments) were tested: control, phosphate, lime, and lime + phosphate, in a completely randomized design and in triplicate (Figure 1). Moisture sensors were installed $0.25 \mathrm{~m}$ below the soil surface to monitor the soil moisture. Porous stainless-steel suction lysimeters (Figure 3 ) were also installed in the soil profile at $60 \mathrm{~cm}$ below the surface of each plot for sampling soil solutions from the water table.

An equivalent to $7 \mathrm{t} \mathrm{ha}^{-1} \mathrm{CaCO}_{3}$ was incorporated to the top $0.10 \mathrm{~m}$ layer for the lime treatment. A pH value above 7.0 was expected due to the most contrasting scenarios among treatments. Phosphate was applied 30 days after the lime in an aqueous solution of monobasic potassium phosphate and dibasic potassium phosphate (50:50), which was enough to reach $0.2 \mathrm{mg}$ phosphorus in the soil solution. The dose of phosphate was based on the phosphate sorption curve for the soil in the experiment. When atrazine was applied, the $\mathrm{pH}$ and base saturation of each treatment were 6 and $40.7 \%$ (control), 7.5 and $80.8 \%$ (with lime), 6.1 and $44.6 \%$ (with phosphate), and 8.3 and $88.7 \%$ (with lime and phosphate).

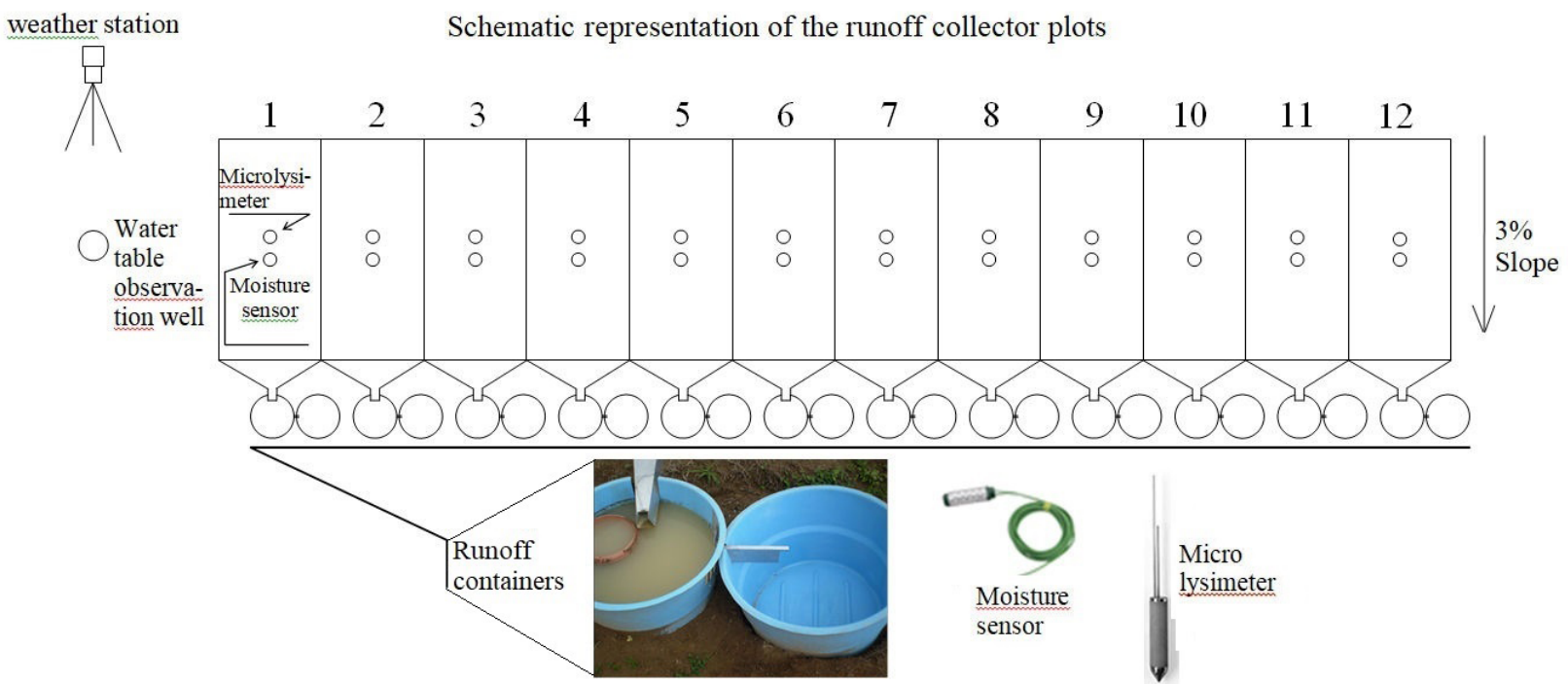

Figure 1: Diagram of the experimental area. Treatments (from left to right) - Plots 1, 8, and 10: with phosphate; plots 3, 6, and 11: control; plots 4, 7, and 12: with lime; and plots 2, 5, and 9: with lime and phosphate. 
Table 1: Chemical attributes in the soil at the first two depths (cm) sixty days after treatments.

\begin{tabular}{crrrrrrrr}
\hline \multirow{2}{*}{ Chemical atribute } & \multicolumn{3}{c}{ Control } & \multicolumn{2}{c}{ Lime } & \multicolumn{2}{c}{ Phosphate } & \multicolumn{2}{c}{ Lime + phosphate } \\
\cline { 2 - 8 } & $0-10$ & $10-20$ & $0-10$ & $10-20$ & $0-10$ & $10-20$ & $0-10$ & $10-20$ \\
\hline $\mathrm{pH}_{\text {water }}$ & 6.0 & 5.7 & 7.5 & 6.1 & 6.1 & 6.0 & 8.3 & 6.3 \\
P-Mel $\left(\mathrm{mg} \mathrm{dm}^{-3}\right)^{1}$ & 3.7 & 3.4 & 4.9 & 2.5 & 4.6 & 3.1 & 5.8 & 4.3 \\
$\mathrm{P}-\mathrm{rem}\left(\mathrm{mg} \mathrm{dm}^{-3}\right)^{2}$ & 30.3 & 25.0 & 31.1 & 26.4 & 32.0 & 26.4 & 26.4 & 27.9 \\
$\mathrm{SB}\left(\mathrm{cmol}_{\mathrm{c}} \mathrm{dm}^{-3}\right)^{3}$ & 2.0 & 1.7 & 5.1 & 2.8 & 2.3 & 1.8 & 7.1 & 2.3 \\
$\mathrm{t}\left(\mathrm{cmol}_{\mathrm{c}} \mathrm{dm}^{-3}\right)^{4}$ & 2.2 & 2.0 & 5.1 & 2.9 & 2.4 & 2.0 & 7.1 & 2.5 \\
$\mathrm{~T}\left(\mathrm{cmol}_{\mathrm{c}} \mathrm{dm}^{-3}\right)^{5}$ & 4.9 & 5.3 & 6.3 & 5.4 & 5.2 & 4.7 & 8.0 & 5.2 \\
${\mathrm{~V}(\%)^{6}}^{6}$ & 40.7 & 32.2 & 80.8 & 51.6 & 44.6 & 37.8 & 88.7 & 44.2 \\
${\mathrm{TOC}\left(\mathrm{g} \mathrm{kg}^{-1}\right)^{7}}^{11.0}$ & 7.3 & 12.5 & 16.2 & 11.0 & 11.8 & 14.7 & 7.3 \\
\hline
\end{tabular}

1P-Mehlich; ${ }^{2}$ P-remaining; ${ }^{3}$ Sum of bases; ${ }^{4} \mathrm{CEC}$ (effective); ${ }^{5} \mathrm{CEC}$ (potential); ${ }^{6}$ Base saturation; ${ }^{7}$ Total organic carbon.

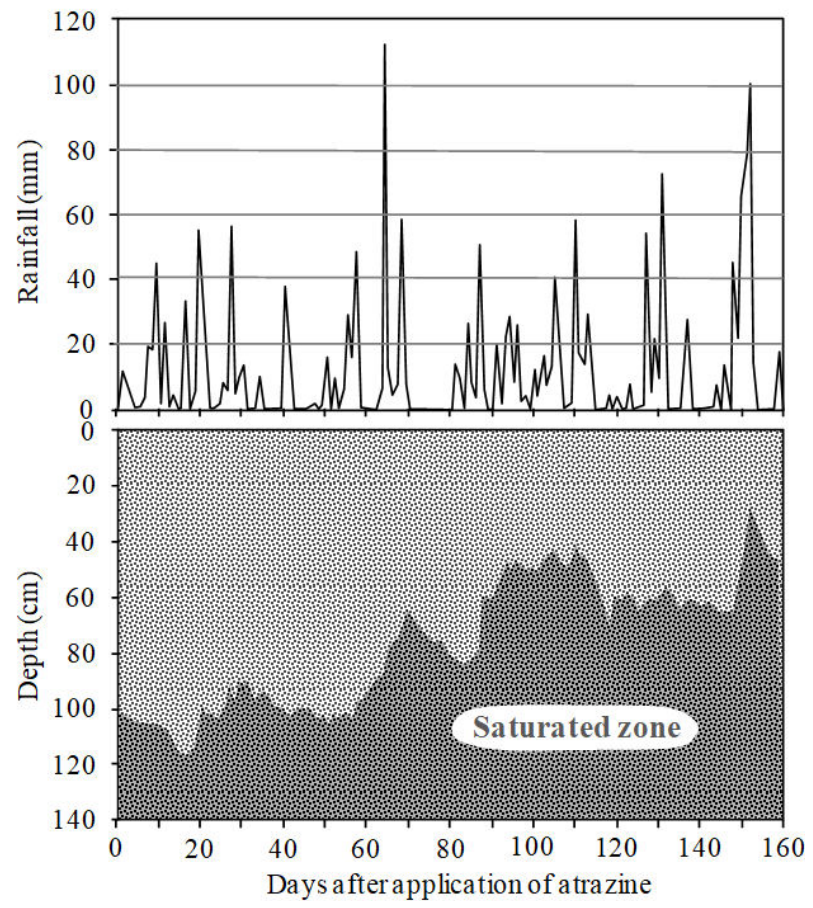

Figure 2: Amount of rainfall and depth of the saturated zone in the soil plots in an Environmental Protection Area in the South of Minas Gerais State - Brazil $\left(21^{\circ}\right.$ $08^{\prime} 18.2^{\prime \prime} \mathrm{S}, 45^{\circ} 22^{\prime} 23^{\prime \prime} \mathrm{W}$ ) during the rainy season of Oct/2007-Apr/2008.

Thirty days after applying $\mathrm{CaCO}_{3}$, phosphate was applied, and thirty days after applying phosphate, atrazine was applied on the surface of each plot, using Gesaprim $500^{\circledR}$ ( $50 \%$ atrazine), corresponding to $1.5 \mathrm{~L} \mathrm{ha}^{-1}$ atrazine, which is the recommended dose for maize fields. The whole experiment was monitored for soil and water parameters during one rainy season (October to April). Soil and water, as well as the sediments in the surface runoff, were analyzed at 112 and 144 days after the application of the herbicide to the plots.

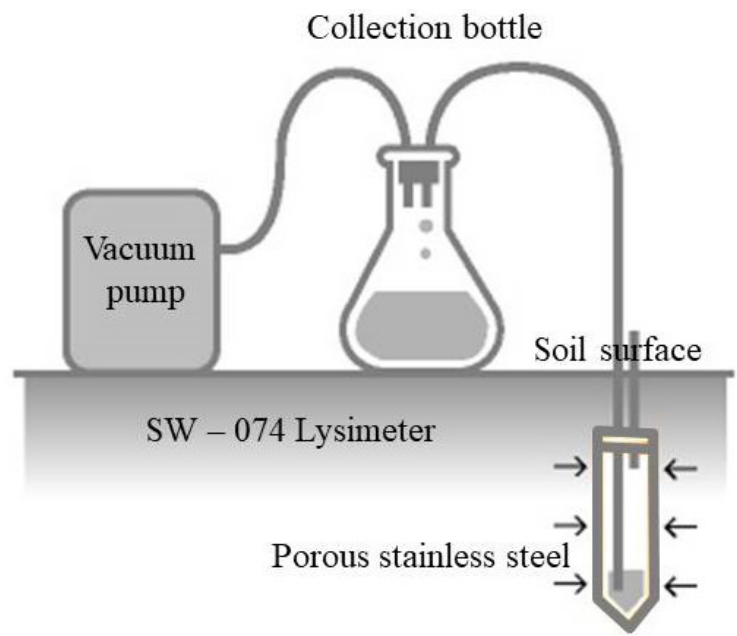

Figure 3: Diagram of the use of a porous steel lysimeter in the soil profile and water table sample collection.

Source: Soil Measurement Systems (Model SW-074 - http://www. soilmeasurement.com/lysimeter.html: Access on March 3, 2020).

\section{Determination of sorption equilibrium time - kinetics}

The equilibrium time was determined using the amount of atrazine that was sorbed at 1, 2, 4, 11, 24, 28, and 48 hours, for samples from $0-0.1$ and $0.40-0.50 \mathrm{~m}$ of depth, which represented, respectively, the A and B horizons of the studied soil. For each sample, in triplicate, $30 \mathrm{~mL}$ centrifuge tubes received $2 \mathrm{~g}$ of soil material (with a precision of $0.1 \mathrm{mg}$ ) and $20 \mathrm{~mL}$ of an aqueous 
solution of $0.01 \mathrm{~mol} \mathrm{~L}^{-1} \mathrm{CaCl}_{2} \cdot 2 \mathrm{H}_{2} \mathrm{O}$ with $3.35 \mu \mathrm{mol} \mathrm{L}-1$, representing $0.72 \mathrm{mg} \mathrm{L}^{-1}$ atrazine. These tubes were shaken on a reciprocal shaking and sets of three samples were removed at each of the above times and centrifuged at 500 $\mathrm{G}$ for 20 minutes. The supernatant was filtered through a $0.22 \mu \mathrm{m}$ PTFE membrane, and the atrazine concentration was quantified employing high-performance liquid chromatography, in a HP 1100 equipment. A standard curve using a $99.5 \%$ pure analytical atrazine standard provided by Syngenta-Brazil was used in this quantification.

The sorbed atrazine was calculated using Equation 1:

$C s\left(m g g^{-1}\right)=(C i-C e) * v / m$,

where $C i$ is the initial concentration of atrazine, $C e$ is the amount of atrazine remained in the solution $\left(\mathrm{mg} \mathrm{L}^{-1}\right)$ after each time, $v$ is the volume of atrazine solution in liters (L), and $m$ is the soil sample mass $(\mathrm{kg})$.

\section{Freundlich model}

The Freundlich model was applied in the sorption results of samples at every $10-\mathrm{cm}$ depth down to $0.70 \mathrm{~m}$, and at $0.90-1.0 \mathrm{~m}$, before the preparation of the soil and plots, and at 0-0.1- and 0.1-0.2-m depths of all the plots, 30 days after the plot preparation and atrazine application. Samples were air-dried and sieved to a $2 \mathrm{~mm}$ size. Subsamples were taken from these samples in triplicate and added to $20 \mathrm{~mL}$ of an aqueous solution of $0.01 \mathrm{~mol}$ $\mathrm{L}^{-1} \mathrm{CaCl}_{2} \cdot \mathrm{H}_{2} \mathrm{O}$ containing atrazine at concentrations of $0.125,0.25,0.5,1,2.5,5,10,20,25$, and $30 \mathrm{mg} \mathrm{L}^{-1}$. These suspensions were shaken for 24 hours, that was enough for the reaction to reach sorption equilibrium according to the kinetic measurement described above.

The sorption isotherms were expressed as $x / m$ $\left(\mu \mathrm{mol} \mathrm{kg}{ }^{-1}\right)$ versus $C e(\mu \mathrm{mol} \mathrm{L}-1)$, fitted to Equation 2 , the Freundlich isotherm equation, which is widely used for pesticides:

$C s=K f C e^{1 / n}$,

where $C s$ represents the amount of sorbed atrazine ( $\mu \mathrm{mol}$ $\left.\mathrm{kg}^{-1}\right), C e$ is the equilibrium concentration $\left(\mu \mathrm{mol} \mathrm{L} \mathrm{L}^{-1}\right) ; K f$ is the "Freundlich" equilibrium constant and $1 / \mathrm{n}$ is an arbitrary constant evaluated by linearizing the equation. If $(1 / n)$ approaches 1 the equation is linear. These Freundlich parameters are obtained with the linearized form of the Freundlich equation (Equation 3):

$\log C s=\log K f+1 / n \log C e$.
For the angular coefficient $(l / n)$ of Equations 2 and 3 near $1.0(0.9<1 / \mathrm{n}>1.1)$, the value of $K f$ represents the partition (or distribution) coefficient between the solid and the liquid phase $(K d)$, as shown in Equation 4:

$K_{d}=\mathrm{Cs}\left(\mu \mathrm{mol} \mathrm{kg}{ }^{-1}\right) / \mathrm{Ce}(\mu \mathrm{mol} \mathrm{L}-1)$.

\section{HPLC Operating Conditions}

In this experiment, an Agilent HP 1100 highperformance liquid chromatography (HPLC) system (Agilent Scientific Instruments, Santa Clara, CA, USA) was used with a diode array detector (DAD), with 222 $\mathrm{nm}$ as the wavelength. The extracts from soil and water samples were eluted through a $5 \mu \mathrm{m}$ and $150 \times 3.2 \mathrm{~mm}$ ODS-2 Waters Spherisorb column, with a mobile-phase methanol/Milli-Q water at a 60:40 ratio, $0.4 \mathrm{~mL} \mathrm{~min}^{-1}$ flow, and $20-\mu \mathrm{L}$ injection volume. Under such conditions, the atrazine retention time was of $6.71 \mathrm{~min}$.

\section{Runoff sampling}

The water and soil sediments from the plots (i.e., the runoff) were stored in two collector boxes connected using a nine-window Geib divisor installed at the bottom of plots (Figure 1). The runoff volumes were measured, and samples corresponding to one liter of runoff water were collected at $14,28,54,69,85,92,112,132$, and 144 days after the herbicide was applied to the plots. These days corresponded to the highest rain events and the proper time in order to avoid overflow of the runoff containers. After each sampling, the containers were emptied, and the total sediments were quantified.

\section{Final soil sampling}

After the 144 days of the monitoring, approximately $2 \mathrm{~kg}$ of soil samples were taken from each plot every 0.1 $\mathrm{m}$ of depth down to $0.5 \mathrm{~m}$, aiming to evaluate the leaching and the potential of contamination along the soil profile. The water, sediment, and soil samples were stored in a cold chamber at $4{ }^{\circ} \mathrm{C}$, in the dark, for further analyses.

\section{Extraction of atrazine from water samples}

Atrazine was separated from the water samples using $180 \mathrm{~mL}$ aliquots of each sample and adding $22.5 \mathrm{~mL}$ of HPLC-grade dichloromethane in separation funnels, which were vertically shaken 50 times in an uniform-circular movement. Then, the dichloromethane containing atrazine was separated, and the dichloromethane was evaporated in a rotary evaporator. This procedure was repeated five times for each aliquot. Then, the dichloromethane was filtered 
$(0.22 \mu \mathrm{m})$ and evaporated completely, and the evaporated residue was washed with $1.0 \mathrm{~mL}$ of mobile phase (i.e., $60 \%$ water and $40 \%$ acetonitrile, V: V), used for the HPLC.

To measure the amount of atrazine recovered in the water extraction method, three distilled water samples were fortified with $1.0 \mu \mathrm{g} \mathrm{L}^{-1}$ atrazine, and another sample was used as a blank. Atrazine was extracted by the process described above, and the amount recovered was of $101.5 \pm 4.7 \%$.

\section{Extraction and purification of atrazine from soil and sediments}

For extracting atrazine from soil and sediments, $100 \mathrm{~mL}$ of HPLC-grade methanol was added to $25 \mathrm{~g}$ of the samples. The suspensions were shaken during $4 \mathrm{~h}$ in a horizontal-orbital shaker at 70 cycles per minute and then kept in the dark for $12 \mathrm{~h}$. The entire supernatants were pipetted, and their volumes were used for the calculation of the herbicide concentrations. These extractions were performed in triplicate.

These supernatants were wholly evaporated at $40{ }^{\circ} \mathrm{C}$, and the residues were dissolved twice with $0.3 \mathrm{~mL}$ of acetone and purified with thin-layer chromatography plates (10- x 20-cm glass plates with $0.5-\mathrm{mm}$ thick layer of silica gel 60GF254-Merck). Chloroform, acetone, and acetic acid were used as the mobile phase at 90:9:1. The elution time of the samples was of $50 \mathrm{~min}$, and the retention factor (Rf) was equivalent to 0.67 . The plates were prepared with a Merck $60 \mathrm{GF}_{254}$ silica gel layer with $0.5 \mathrm{~mm}$ thickness.

Atrazine was identified on the TLC plates using reference points on their sides, applying an atrazine solution concentrated enough to appear as dark points under UV light $(254 \mathrm{~nm})$. The areas corresponding to atrazine were carefully scraped and transferred to number 2 Whatman filters. The atrazine in the silica was eluted with $15 \mathrm{~mL}$ of acetone, totally evaporated, and dissolved in $1.0 \mathrm{~mL}$ of acetonitrile and Milli-Q water $(40: 60, \mathrm{~V}: \mathrm{V})$, used as the mobile phase for HPLC.

To evaluate the percentage of recovering of atrazine in this soil extraction method, a soil sample with $6 \%$ organic matter and no herbicide residue was used. Three samples were spiked with $1.0 \mathrm{mg} \mathrm{L}^{-1}$ of the herbicide, while another sample was used as a control. The atrazine was extracted through the process described above, and the recovery value was of $91.5 \pm 3.2$.

The atrazine was quantified by HPLC using a diode array detector (DAD) at $222 \mathrm{~nm}$, injecting a $5-\mu \mathrm{m}$ aliquot using a $150-\mathrm{x} 3$ 3.2-mm ODS-2 Waters Spherisorb column. The mobile phase was 60:40 (V:V) Milli-Q water and acetonitrile, with $0.4 \mathrm{~mL} \mathrm{~min}^{-1}$ flow and $100 \mu \mathrm{L}$ injection volume. Under these conditions, the retention time was of 9.52 minutes.
The detection limit of the chromatograph was of 2 $\mu \mathrm{g} \mathrm{L}^{-1}$ for the water sample analyses, and of $4 \mu \mathrm{g} \mathrm{L}^{-1}$ for the soil sample analyses, considering a signal-to-noise ratio of at least 3 . The detection limits of the whole method were $0.01 \mu \mathrm{g} \mathrm{L}^{-1}$ for the water samples, which were 200 fold concentrated, and $0.16 \mu \mathrm{g} \mathrm{L}^{-1}$ for the soil samples, which were 25 fold concentrated.

The physical characterization of soil was performed using the pipette method for particle size distribution.

\section{RESULTS AND DISCUSSION}

\section{Sorption of atrazine}

In a previous kinetics assay, it was found that $24 \mathrm{~h}$ of shaking was enough time to achieve equilibrium, and it did not differ between the two soil layers (Figure 4). On the other hand, sorption capacity differed among the samples from the two depths $(0-10$ and $40-50 \mathrm{~cm})$, which is primarily related to the organic matter and clay contents of the samples.

The 24-h shaking period used in this study was defined according to the results in Table 2.

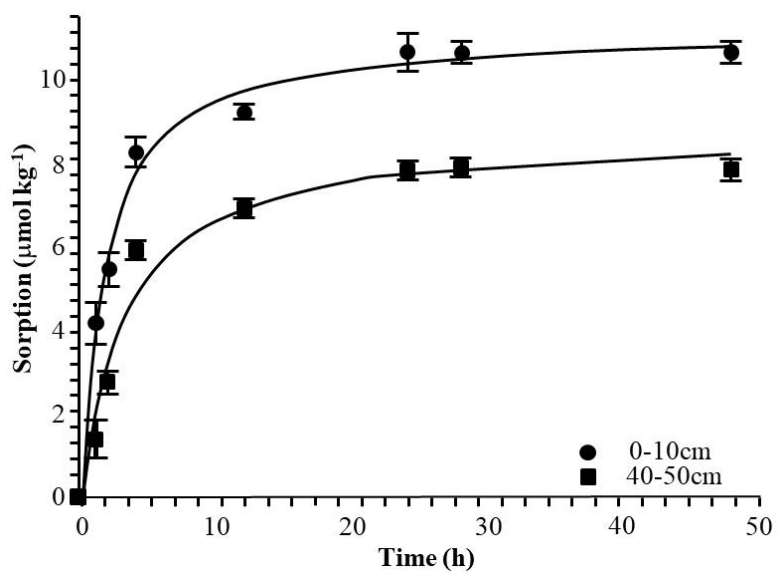

Figure 4: Sorption of atrazine in a Typic Hapludult as a function of the sampling layer and shaking time with an aqueous solution of $3.35 \mu \mathrm{mol} \mathrm{L}^{-1}$. Error bars represente the standar deviation of means.

\section{Sorption of atrazine in the soil before the lime and phosphate treatments}

The amount of sorbed atrazine related as a function of equilibrium concentration in solution was fitted to the linearized Freundlich equation in order to determine the sorption coefficient (Kf) and curve slope $(1 / n)$ for the soil profile at different depths. The sorption data were adjusted 
to this linear model accordingly $\left(\mathrm{R}^{2} \geq 0.96\right)$, with $\mathrm{l} / \mathrm{n}$ values ranging between 0.97 and 1.09, as shown in Figure 5.

As expected, the atrazine sorption decreased with the percentage of organic carbon in the samples. Since $1 / \mathrm{n}$ values are between 0.97 and 1.09, the isotherms are basically linear. Therefore, $\mathrm{Kf}$ values from these isotherms can express the distribution or partition coefficient (Kd). The coefficients of correlation between $\mathrm{Kf}$ and the percentage of organic carbon in the samples were above 0.95 (Table 3).

Sorption of atrazine in the samples from $30 \mathrm{~cm}$ or deeper was much lower than that for the top layer of the soil profile. Therefore, below $30 \mathrm{~cm}$, more atrazine is more in the soil solution than sorbed into the particles $(\mathrm{Kd}<1)$, as there is a reduction in the organic carbon. Under this condition, groundwater may easily be contaminated since the water table is closer to the soil surface, especially at this position of the landscape, which is not far from the floodplain, notably during the rainiest periods (Figure 2). From 83 days until the last sampling of water in the soil profile, the depth of the water table ranged from $0.6 \mathrm{~m}$ deep to about $40 \mathrm{~cm}$ deep, that caused dilution of the atrazine amount, independently of the treatment. Therefore, the amount of rain in this period caused dilution of atrazine to levels below the tolerable to be in the drink water, as will be discussed ahead.

Table 2: Sorption of atrazine in samples of 0-10 e 40-50-cm layers of a Typic Hapludult as a function of time.

\begin{tabular}{|c|c|c|c|c|}
\hline \multirow{3}{*}{$\frac{\text { Time }(\mathrm{h})}{1}$} & \multicolumn{4}{|c|}{ Sorption $\left(\mu \mathrm{mol} \mathrm{kg}{ }^{-1}\right)$} \\
\hline & \multicolumn{2}{|c|}{$0-10 \mathrm{~cm}^{*}$} & \multicolumn{2}{|c|}{$40-50 \mathrm{~cm}$ ** } \\
\hline & $4.201 \mathrm{a}$ & $( \pm 0.002)$ & $1.406 \mathrm{a}$ & $( \pm 0.003)$ \\
\hline 2 & $5.619 b$ & $( \pm 0.029)$ & $2.819 \mathrm{~b}$ & $( \pm 0.037)$ \\
\hline 4 & $8.313 c$ & $( \pm 0.020)$ & $6.003 c$ & $( \pm 0.005)$ \\
\hline 11 & $9.326 \mathrm{~d}$ & $( \pm 0.039)$ & $7.021 \mathrm{~d}$ & $( \pm 0.035)$ \\
\hline 24 & $10.767 \mathrm{e}$ & $( \pm 0.100)$ & $7.931 \mathrm{e}$ & $( \pm 0.091)$ \\
\hline 28 & $10.769 \mathrm{e}$ & $( \pm 0.104)$ & 7.942 e & $( \pm 0.095)$ \\
\hline 48 & $10.778 \mathrm{e}$ & $( \pm 0.036)$ & 7.943 e & $( \pm 0.033)$ \\
\hline
\end{tabular}

${ }^{*} \mathrm{CV}=0.25 \% ;{ }^{* *} \mathrm{CV}=0.15 \%$. ${ }^{*}$ Means followed by the same letter do not differ according to Scott Knott test, at $5 \%$ of probability.

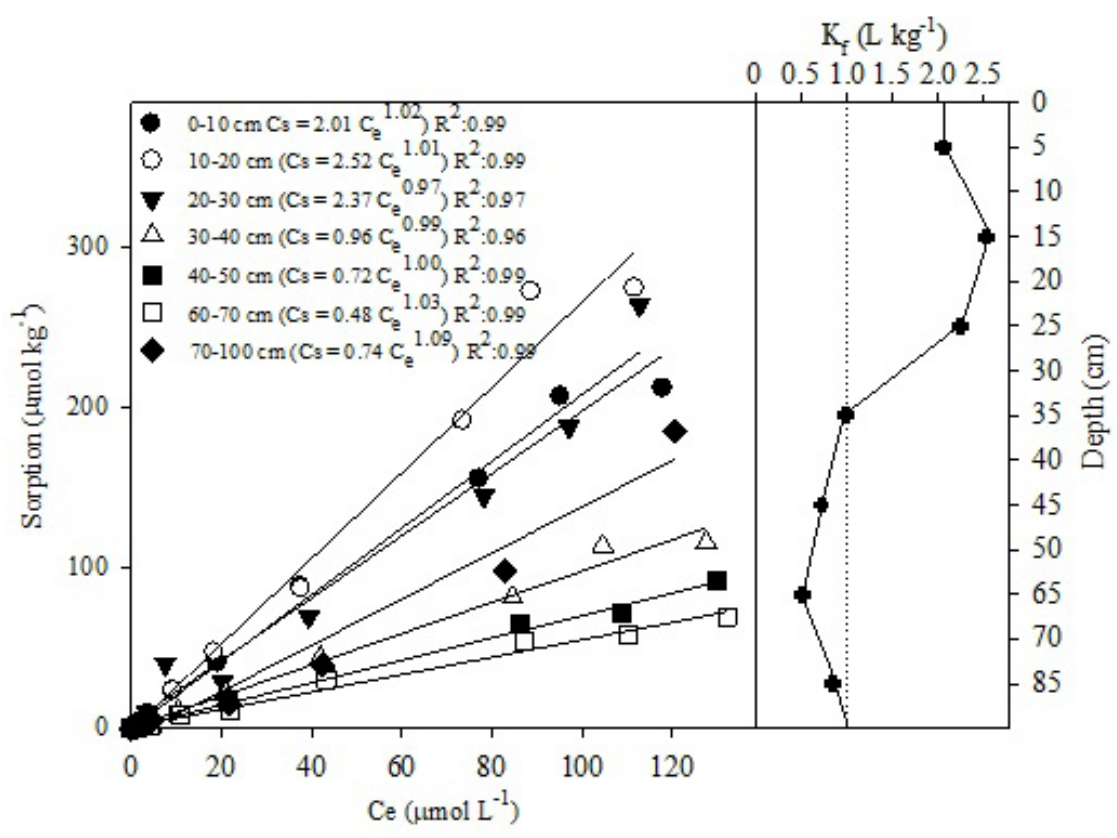

Figure 5: Freundlich isotherms adjusted to describe atrazine sorption in a Typic Hapludult at every 10-cm layer, down to $1 \mathrm{~m}$ in the soil profile. 
Table 3: Freundlich parameters, correlation, organic carbon, and $\mathrm{K}_{\mathrm{oc}}$ of sorption of atrazine in different depths of a Typic Hapludult.

\begin{tabular}{cccccc}
\hline \multirow{2}{*}{ Depth $(\mathrm{cm})$} & $\mathrm{Kf}$ & $1 / \mathrm{n}$ & $\mathrm{R}^{2}$ & $\mathrm{OC}$ & $\mathrm{K}_{\mathrm{oc}}$ \\
\hline $0-10$ & $2.01( \pm 0.14)^{*}$ & 1.02 & 0.99 & 9.2 & $218( \pm 15)$ \\
$10-20$ & $2.52( \pm 0.09)$ & 1.01 & 0.99 & 11.0 & $229( \pm 08)$ \\
$20-30$ & $2.37( \pm 0.08)$ & 0.97 & 0.97 & 7.6 & $312( \pm 10)$ \\
$30-40$ & $0.96( \pm 0.11)$ & 0.99 & 0.96 & 6.9 & $139( \pm 16)$ \\
$40-50$ & $0.72( \pm 0.07)$ & 1.00 & 0.99 & 3.5 & $206( \pm 20)$ \\
$60-70$ & $0.48( \pm 0.08)$ & 1.03 & 0.99 & 2.3 & $209( \pm 34)$ \\
$70-100$ & $0.74( \pm 0.13)$ & 1.09 & 0.99 & 4.6 & $161( \pm 28)$ \\
\hline
\end{tabular}

* Numbers in parentheses represent standard deviations $(n=3)$.

\section{Sorption of atrazine in the soil after the lime and phosphate treatments}

The effect of lime was more pronounced at the $0-0.1$ m depth, sixty days after the treatment, with no impact below this layer. In its turn, phosphate was found deeper than calcium, since it was applied to soil as an aqueous solution and leached a little more than the treatment with lime (Table 1). The atrazine sorption isotherms as well as $\mathrm{pH}$, organic carbon, and distribution (partitioning) coefficients for the soil samples after the lime and lime+phosphate treatments are presented in Tables 4 and 5, respectively. As found for non-treated soil, the sorption correlated linearly to the equilibrium concentration of atrazine. The $\mathrm{Kd}$ values ranged from 1.33 to $3.0 \mathrm{~L} \mathrm{~kg}^{-1}$.

The sorption of atrazine changed accordingly to the treatments. Both lime and phosphate reduced the sorption, when compared to that of the control.

Higher soil $\mathrm{pH}$ values account for more negative charges within organic matter as well as the deprotonated form of atrazine molecules, consequently reducing the hydrophobic partitioning and increasing the sorption on charged particles. Therefore, the reaction is $\mathrm{pH}$-dependent and come from protonated forms (Colombini et al., 1998). The adsorption of atrazine by humic acid was weak, involving hydrogen bonding, proton transfer, and possible hydrophobic bonding. At $\mathrm{pH}$ values above 3 , less than $1 \%$ of the atrazine molecules are in a protonated form (Martin-Neto; Vieira; Sposito, 1994). In its neutral form, organic matter is the only soil fraction that accounted for the atrazine sorption, with the mineral fraction having little or none effect.

\section{Residue of atrazine in the soil profile}

The presence of atrazine left in the soil profile after the rainy season was determined in the soil 144 days after its application on the plots. At this time, the water table (saturated zone) was about $40 \mathrm{~cm}$ from the soil surface (Figure 2). The amount of rainfall during this period was of $1,595 \mathrm{~mm}$; about $80 \%$ of this precipitation infiltrated into the soil.

For the plots with no treatments (i.e., control) and with phosphate, higher amounts of atrazine were found closer to the soil surface, compared to plots with lime and lime + phosphate. When lime and lime + phosphate were applied to the soil, higher amounts of atrazine were found deeper in the soil profile, closer to the saturated zone. Therefore, groundwater contamination is more likely to happen when lime, and mainly lime + phosphate, are applied, which means that liming the soil has more effect on decreasing sorption of atrazine, since phosphate alone did not affect that much (Figure 6).

Atrazine was found below $50 \mathrm{~cm}$ in the soil profile, 90 days after its application, reaching greater depths in the soil profile. In a previous study, in a similar soil class, Correia et al. (2007) also found, in field experiments, that atrazine was detected at a depth of $50 \mathrm{~cm}$, indicating leaching. They also found that, under simulated rain, $0.5 \%$ of atrazine was adsorbed onto transported soil particles and $1.6 \%$ was in solution.

The lower sorption of atrazine in soil when lime and lime + phosphate were applied was due to the changes to the electrochemical behavior of the colloids as a consequence of increasing the $\mathrm{pH}$ and ionic strength, among other factors, in the soil solution. Sorption negative sites on organic matter and clay particles increase with increasing $\mathrm{pH}$, as well as dissolution of part of organic matter, resulting in the reduction atrazine adsorption (Tao; Tang, 2004). However, increasing $\mathrm{pH}$ also increases deprotonation of atrazine and decrease sorption by physical adsorption, which increases hydrophobic partitioning interaction among atrazine molecules and the soil (Yue et al, 2017). 
Table 4: Freundlich isotherms adjusted for atrazine sorption at different treatment conditions in two layers of a Typic Hapludult.

\begin{tabular}{ccc}
\hline \multirow{2}{*}{ Treatments } & \multicolumn{2}{c}{ Freundlich isotherms } \\
\cline { 2 - 3 } & $0-10 \mathrm{~cm}$ & $10-20 \mathrm{~cm}$ \\
\hline Control & $\mathrm{C}_{\mathrm{s}}=2.61 \mathrm{C}_{\mathrm{e}}^{1.01} \mathrm{R}^{2}=0.99$ & $\mathrm{C}_{\mathrm{s}}=3.0 \mathrm{C}_{\mathrm{e}}{ }^{0.97} \mathrm{R}^{2}=0.98$ \\
Phosphate & $\mathrm{C}_{\mathrm{s}}=1.94 \mathrm{C}_{\mathrm{e}}^{1.02} \mathrm{R}^{2}=0.99$ & $\mathrm{C}_{\mathrm{s}}=2.09 \mathrm{C}_{\mathrm{e}}{ }^{1.02} \mathrm{R}^{2}=0.99$ \\
Lime & $\mathrm{C}_{\mathrm{s}}=1.40 \mathrm{C}_{\mathrm{e}}^{1.02} \mathrm{R}^{2}=0.99$ & $\mathrm{C}_{\mathrm{s}}=2.53 \mathrm{C}_{\mathrm{e}}{ }^{1.01} \mathrm{R}^{2}=0.99$ \\
Lime and phosphate & $\mathrm{C}_{\mathrm{s}}=1.33 \mathrm{C}_{\mathrm{e}}{ }^{1.03} \mathrm{R}^{2}=0.99$ & $\mathrm{C}_{\mathrm{s}}=2.05 \mathrm{C}_{\mathrm{e}}{ }^{1.02} \mathrm{R}^{2}=0.99$ \\
\hline
\end{tabular}

Table 5: Partition coefficient ( $\left.\mathrm{L} \mathrm{kg}^{-1}\right)$ and average $\mathrm{pH}$ values for two layers of a Typic Hapludult using lime, phosphate, and lime + phosphate.

\begin{tabular}{ccccccc}
\hline Treatments & $\mathrm{Kd}$ & $\mathrm{Koc}$ & $\mathrm{pH}$ & $\mathrm{Kd}$ & $\mathrm{Koc}$ & $\mathrm{pH}$ \\
\hline Control & $2.61 \mathrm{aB}$ & 237 & $6.10 \mathrm{~cm}$ & $3.00 \mathrm{aA}$ & 411 & 5.8 \\
Phosphate & $1.94 \mathrm{bA}$ & 155 & 6.5 & $2.09 \mathrm{cA}$ & 129 & 6.1 \\
Lime & $1.47 \mathrm{cB}$ & 134 & 7.6 & $2.53 \mathrm{bA}$ & 214 & 6.6 \\
Lime and phosphate & $1.33 \mathrm{~dB}$ & 90 & 8.3 & $2.05 \mathrm{cA}$ & 281 & 6.4 \\
\hline
\end{tabular}

Means followed by the same lower-case letter in the columns ( $C V=9.14 \%)$ and upper-case letter in the lines ( $C V=4.13 \%)$ do not differ from each other according to the Scott-Knott test at the 5\% significance level.

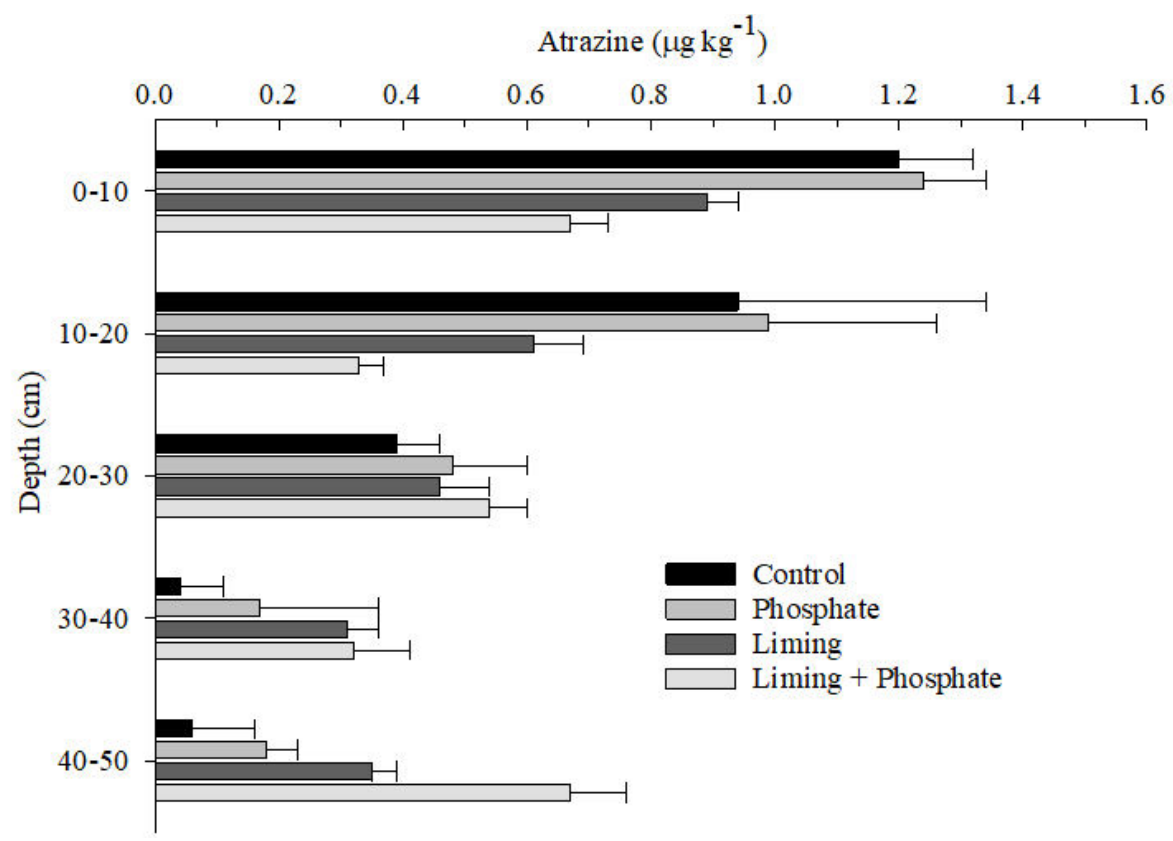

Figure 6: Atrazine leaching in the soil profile of a Typic Hapludult at 144 days after the herbicide application. Error bars represent Standard Deviation of means $(n=3)$. 


\section{Presence of atrazine in the solid part of runoff}

The amount of atrazine in the sediments, the amount of sediment at 85,132 , and 144 days after the herbicide was applied to the plots are presented in Table 6. Atrazine was found in all the sediment samples, with higher amounts in those from the limed plots. Sediments in the control plot samples also presented significant concentrations of atrazine, which is due to its higher capacity to be sorbed to the organic matter on the surface (Table 5).

After 132 days, the treatments that received phosphate presented lower amounts of atrazine in the sediments (Table 6), indicating that the effects of phosphate on soil dispersion and the release of organic carbon into solution were less than those observed for the treatments with lime and lime + phosphate.

There is no specific legislation for atrazine concentration in tropical soils, so it is not possible to establish the level of contamination in these plots. However, the Brazilian Control Agency CETESB, for São Paulo State - Brazil, has adopted the Soil Protection Act references introduced by the Netherlands government in 1994 as a reference for contaminants. The amounts found in this study and comparison of them with the norms in USA and Brazil will be shown ahead in this text.

\section{Presence of atrazine in liquid part of the runoff}

The atrazine contents in the water of runoff from the plots with lime + phosphate are shown in Table 6 , along with the amount of runoff, precipitation, and sediment. The $\mathrm{pH}$ value of the water ranged between 6.3 and 6.7.

The runoff was sampled between 14 and 144 days after the atrazine application. Most of the atrazine in the water of runoff was found in the samples of 14 and 28 days (Table 7). These days are in the beginning of the rainy season, which corresponds to the period of germination and initial growth of maize in the studied region, so there is little surface coverage to protect the soil against erosion. Since atrazine was already on the soil, this favors contamination in adjacent areas (e.g., rivers, lakes, and floodplains, among others).

Even with runoff being about $1 \%$ of the total rain, the highest concentrations of atrazine were found 14 days after application, because there was more atrazine to be transported (Table 7). For the later events, atrazine degradation and its sorption to the sediments accounted for the lower amounts of atrazine in the runoff water.

Table 6: Atrazine in the solid part of runoff in different soil condition of a Typik Hapludult in the South of Minas Gerais, Brazil.

\begin{tabular}{|c|c|c|c|}
\hline Treatments & Atrazine residue & Soil loss (Kg ha-1) & Total atrazine loss \\
\hline & $\left(\mu \mathrm{g} \mathrm{Kg}^{-1}\right)$ & period (days) & $\left(\mu \mathrm{g} \mathrm{ha} a^{-1}\right)$ \\
\hline \multicolumn{4}{|c|}{$1-85^{*}$} \\
\hline Control & $0.35 \mathrm{~b}$ & 83.70 & 29.30 \\
\hline Phosphate & $0.29 \mathrm{~b}$ & 141.40 & 41.00 \\
\hline Lime & $1.07 \mathrm{a}$ & 365.00 & 390.55 \\
\hline Lime and phosphate & $0.57 \mathrm{~b}$ & 125.73 & 71.67 \\
\hline \multicolumn{4}{|c|}{$86-132$ ** } \\
\hline Control & $0.25 \mathrm{~b}$ & 38.07 & 9.52 \\
\hline Phosphate & nd & 30.67 & nd \\
\hline Lime & $0.34 \mathrm{a}$ & 39.20 & 13.33 \\
\hline Lime and phosphate & nd & 25.73 & nd \\
\hline \multicolumn{4}{|c|}{$133-144$ *** } \\
\hline Control & $0.20 \mathrm{~b}$ & 153.84 & 30.57 \\
\hline Phosphate & nd & 160.01 & nd \\
\hline Lime & $0.26 \mathrm{a}$ & 178.27 & 46.35 \\
\hline Lime and phosphate & nd & 208.47 & nd \\
\hline
\end{tabular}


Table 7: Atrazine water of runoff, runoff volume, precipitation in different periods for the experimental area with different treatments in a Typic Hapludult in the South of Minas Gerais, Brazil.

\begin{tabular}{|c|c|c|c|c|c|c|c|c|c|c|}
\hline \multirow{3}{*}{$\begin{array}{c}\text { DAA } \\
\text { (Days) }\end{array}$} & \multicolumn{4}{|c|}{ Atrazine herbicide residue } & \multirow{3}{*}{$\frac{\mathrm{Cl} \text { * }}{\text { (Days) }}$} & \multicolumn{5}{|c|}{ Water/sediment collection device } \\
\hline & C & $P$ & $\mathrm{~L}$ & $L+P$ & & \multirow{2}{*}{$P P^{* *}$} & \multicolumn{4}{|c|}{ Runoff*** } \\
\hline & \multicolumn{4}{|c|}{$\left(\mu \mathrm{g} \mathrm{L}^{-1}\right)$} & & & C & $\mathrm{P}$ & $\mathrm{L}$ & $L+P$ \\
\hline 14 & 13.73 & 39.61 & 42.82 & 9.04 & 14 & 143 & 1.4 & 3.5 & 1.4 & 1.0 \\
\hline 28 & 11.99 & 5.0 & 0.56 & 2.65 & 14 & 109 & 1.0 & 4.3 & 1.1 & 2.1 \\
\hline 54 & 0.66 & 0.67 & 2.01 & 1.59 & 16 & 133 & 14.7 & 17.7 & 17.7 & 17.7 \\
\hline 69 & 0.77 & 0.61 & 0.68 & 0.61 & 15 & 225 & 3.1 & 13.7 & 21.3 & 5.8 \\
\hline 85 & 0.12 & 0.60 & 0.50 & 0.52 & 16 & 136 & 17.7 & 49.2 & 64.2 & 17.7 \\
\hline 92 & 0.12 & 0.52 & 0.04 & 0.09 & 07 & 81 & 9.6 & 11.9 & 13.4 & 14.4 \\
\hline 112 & 0.80 & 0.34 & 0.34 & 0.07 & 10 & 237 & 2.7 & 2.3 & 3.3 & 3.4 \\
\hline 132 & 0.05 & 0.05 & 0.12 & 0.06 & 20 & 207 & 15.9 & 13.9 & 12.7 & 12.9 \\
\hline 144 & 0.04 & 0.05 & 0.11 & 0.07 & 12 & 324 & 17.7 & 53.7 & 17.7 & 17.7 \\
\hline Total & 30.08 & 49.44 & 48.98 & 24.67 & - & 1595 & 83.9 & 170.2 & 152.6 & 116.2 \\
\hline
\end{tabular}

*The collection time did not coincide with the number of days after the application because the atrazine content in water was not analyzed for all samples collected. ** PP: precipitation $(\mathrm{mm}) .{ }^{* *}$ Liters. DAA is the number of days after the herbicide application; C = Control; P: P Treatment; L: Lime treatment; L + P: Lime + P treatment.

The treatments only affected the herbicide's concentration in the runoff water in the first two samplings. Most of the atrazine levels in the runoff water were below $2.0 \mu \mathrm{g} \mathrm{L}^{-1}$, the maximum allowed limit, defined by the Quality Control and Surveillance Water for Human Consumption and its Potability Standard (Brazilian National Health Foundation, 2001),

\section{Atrazine residue in the groundwater}

Samples were suctioned using a porous stainless steel lysimeter at a depth of $60 \mathrm{~cm}$ at 112 and 144 days after atrazine was applied (Table 8). Most of the samples presented less than $2.0 \mu \mathrm{g} \mathrm{L}^{-1}$, with the concentrations at 112 days being higher than those at 144 days. From 112 to 144 days, the saturated zone of the soil was 40 to $70 \mathrm{~cm}$ deep (Figure 2). This concentration is below the maximum contaminant level goals - MCLG, which is $0.003 \mathrm{mg} \mathrm{L}^{-1}\left(3 \mu \mathrm{g} \mathrm{L}^{-1}\right)$, according to drinking water regulations for atrazine of the USA Environmental Protection Agency - EPA (2009) and the Quality Control and Surveillance Water for Human Consumption and its Potability Standard (Brazilian National Health Foundation, 2001), which is $2.0 \mu \mathrm{g} \mathrm{L}^{-1}$.
Table 8: Atrazine residue in the water table taken 0.6 $\mathrm{m}$ below the soil surface $\left(\mu \mathrm{g} \mathrm{L^{-1 }}\right)$.

\begin{tabular}{ccc}
\hline Treatment & \multicolumn{2}{c}{$\begin{array}{c}\text { Days after application of } \\
\text { atrazine }\end{array}$} \\
\hline & 112 days & 144 days \\
\hline Control & 0.050 & 0.020 \\
Phosphate & 0.060 & nd \\
Lime & 0.050 & nd \\
Lime and phosphate & 0.070 & nd \\
\hline
\end{tabular}

$\mathrm{nd}=$ atrazine residue not detected.

\section{CONCLUSIONS}

Partition coefficients (Kd) were lower $<1 \mathrm{~L} \mathrm{~kg}^{-1}$ in the layers below $35 \mathrm{~cm}$. Lime and lime + phosphate reduced sorption and increased leaching of atrazine in the soil. Atrazine was found in both, liquid and solid, of the runoff up to 144 days after its application to the soil. Atrazine found in the water table ranged between 0.05 and $0.07 \mu \mathrm{g} \mathrm{L}^{-1}$ at 112 days, and it was at most $0.02 \mu \mathrm{g} \mathrm{L}{ }^{-1}$ at 144 days. Amount of rainfall and water infiltration were enough to dilute atrazine in the groundwater at the end of the rainy season. 


\section{ACKNOWLEDGEMENTS}

The authors express their gratitude to Fapemig, the Foundation for Research Support of the Brazilian state of Minas Gerais, and to CNPq, the Brazilian National Council for Science and Technology, for their financial support and scholarships to this research.

\section{REFERENCES}

AQUINO, R. F. et al. Atrazine in a corn cultivated area and its relation with the landscape position. Ciência e Agrotecnologia, 37(5):389-396, 2013.

ARORA, S.; SAHNI, D. Pesticides effect on soil microbial ecology and enzyme activity - An overview. Journal of Applied and Natural Science, 8(2):1126-1132, 2016.

BARRIOS, R. E. et al. Enhanced biodegradation of atrazine at high infiltration rates in agricultural soils. Environmental Science: Processes \& Impacts. 21:999-1010, 2019.

BRAZILIAN NATIONAL HEALTH FOUNDATION. Ordinance No. 1,469 - Quality control and surveillance water for human consumption and its potability standard. Brasília: Fundação Nacional de Saúde, 2001. 32p.

CLAY, S. A. et al. Differences in herbicide adsorption on soil using several soil $\mathrm{pH}$ modification techniques. Journal of Environmental Science and Health, 23(6):559-573, 1988.

COLOMBINI, M. P. et al. Protonation and degradation reactions of s-Triazine Herbicides. Microchemical Journal, 59:239245, 1998.

CORREIA, F. V. et al. Atrazine sorption and fate in a Ultisol from humid tropical Brazil. Chemosphere, 67(5):847-854, 2007.

DIAS, A. C. L et al. Occurrence of atrazine in Brazilian water and removal by water treatment: Systematic review. Revista Internacional de Ciências, 8(2):234-253, 2018.

EMBRAPA - EMPRESA BRASILEIRA DE PESQUISAAGROPECUÁRIA. Manual de Métodos de Análise de Solos. $3^{\text {rd }}$ ed., Revised, Rio de Janeiro, 2017. 574p.

HERWIG, U. et al. Physicochemical interactions between atrazine and clay minerals. Applied Clay Science, 18(56):211-222, 2001.

KLOSTER, N. et al. Aggregation kinetics of humic acids in the presence of calcium ions. Colloids and Surfaces $\mathbf{A}$ : Physicochemical and Engineering Aspects, 427(20):7682, 2013.
KOTTEK, M. et al. Climate classification updated. Meteorologische Zeitschrift. 15(3):259-263, 2006.

LAIRD, D. A. et al. Sorption of atrazine on soil clay components. Environmental Science \& Technology, 28(6):1054-1061, 1994.

MARTIN-NETO, L.; VIEIRA, E. M.; SPOSITO, G. Mechanism of atrazine sorption by humic acid: A spectroscopic study. Environmental Science \& Technology, 28(11):1867-1873, 1994.

MARTINS, E. C. et al. Sorption and desorption of atrazine on soils: The effect of different soil fractions. Geoderma, 322:131-139, 2018.

MUDHOO, A.; GARG, V. K. Sorption, transport and transformation of atrazine in soils, minerals and composts: A Review. Pedosphere, 21(1):11-25, 2011.

OLIVEIRAJUNIOR, S.; KOSKINEN, W. C.; FERREIRA, F. A. Sorption and leaching potential of herbicides on Brazilian soils. Weed Research, 41:97-110, 2001.

OUYANG, W. et al. Optimization of typical diffuse herbicide pollution control by soil amendment configurations under four levels of rainfall intensities. Journal of Environmental Economics and Management, 175:1-8, 2016.

PIGNATI, W. A. et al. Spatial distribution of pesticide use in Brazil: A strategy for Health Surveillance. Ciência \& Saúde Coletiva, 22(10):3281-3293, 2017.

SANTOS, H. G. et al. Sistema brasileiro de classificação de solos. 5a . ed. Brasília: Embrapa, 2018. Available in: <http:// ainfo.cnptia.embrapa.br/digital/bitstream/item/199517/1/ SiBCS-2018-ISBN-9788570358004.pdf>. Access in: February 21, 2020.

SASS, J. B.; COLANGELO, A. European union bans atrazine, While the United States negotiates continued use. International Journal of Occupational and Environmental Health, 12(3):260-267, 2006.

SOIL SURVEY STAFF. Keys to soil taxonomy. $12^{\text {th }}$ ed. Washington, DC: United States Department of Agriculture, Natural Resources Conservation Service, 2014. Available in: <https://www.nrcs.usda.gov/wps/portal/nrcs/detail/soils/ survey/class/taxonomy/?cid=nrcs142p2_053580>. Access in: February 21, 2020.

SPARK, K. M.; SWITH, R. S. Effect of soil composition and dissolved organic matter on pesticide sorption. Science of The Total Environment, 298(1-3):147-161, 2002. 
TAO, Q. H.; TANG, H. X. Study on the sorption behavior of atrazine by natural aquatic sediments. Environmental Chemistry, 23:145-151, 2004.

USA ENVIRONMENTAL PROTECTION AGENCY - EPA. Atrazine - Background and Updates. 2016. Available in: <https:// www.epa.gov/ingredients-used-pesticide-products/atrazinebackground-and-updates>. Access in: September 11, 2019.

USA ENVIRONMENTAL PROTECTION AGENCY - EPA. Ground Water and Drinking Water: National Primary Drinking Water Regulation Table. 2009. Available in: <https:// safewater.zendesk.com/hc/en-us/articles/212077787-4What-are-EPA-s-drinking-water-regulations-for-atrazine->. Access in: September 18, 2019.

VONBERG, D. et al. Atrazine soil core residue analysis from an agricultural field 21 years after its ban. Journal of Environmental Quality, 43(4):1450-1459, 2014.

YUE, L. et al. Adsorption-desorption behavior of atrazine on agricultural soils in China. Journal of Environmental Sciences, 57:180-189, 2017. 